\title{
Campyloneurum C. Presl (Polypodiaceae) no Estado de São Paulo, Brasil
}

\author{
Diego T. Vasques ${ }^{1,3}$ e Jefferson Prado ${ }^{2}$
}

Recebido: 11.09.2010; aceito: 14.04.2011

\begin{abstract}
Campyloneurum C. Presl (Polypodiaceae) in São Paulo State, Brazil). Campyloneurum belongs to the family Polypodiaceae, which is hardly characterized by a few morphological characters. Presl segregated the gender Campyloneurum from Polypodium L. in 1836, and recognized 11 species. The objective of this research is to accomplish a floristic survey of Campyloneurum species in São Paulo State. Were realized fieldwork and an extension revision of collections from the main herbaria in the State. Based on morphological characters nine species were recognized and also are presented an identification key, descriptions, comments, geographical distribution maps, and illustrations for all the studied species.
\end{abstract}

Key words: diversity, ferns, flora, Polypodiopsida

RESUMO - (Campyloneurum C. Presl (Polypodiaceae) no Estado de São Paulo, Brasil). Campyloneurum pertence à família Polypodiaceae, a qual é de difícil circunscrição através de poucos caracteres morfológicos. Presl segregou o gênero Campyloneurum de Polypodium L. em 1836 e reconheceu 11 espécies. O objetivo deste estudo é apresentar o levantamento florístico das espécies de Campyloneurum no Estado de São Paulo. Foram realizadas coletas e uma extensa revisão das coleções dos principais herbários do estado. Baseado em caracteres morfológicos, nove espécies foram reconhecidas, sendo apresentadas chave de identificação, descrições, comentários, mapas de distribuição geográfica e ilustrações para todas as espécies estudadas.

Palavras-chave: diversidade, flora, Polypodiopsida, samambaias

\section{Introdução}

De acordo com Smith et al. (2006), a família Polypodiaceae pertence à ordem Polypodiales (Polypodiopsida) e está incluída no clado dos Eupolipoides I, estando bastante relacionada filogeneticamente às famílias Davalliaceae, Oleandraceae, Tectariaceae, Lomariopsidaceae e Dryopteridaceae. Polypodiaceae possui distribuição cosmopolita, contendo cerca de 40 gêneros e 1.000 espécies (Smith et al. 2006). É uma família grande e que não pode ser definida por apenas uma característica morfológica (Boldrin \& Prado 2007).

De acordo com a classificação de Smith et al. (2006), a circunscrição da família engloba representantes de outras famílias recentemente adotadas em trabalhos taxonômicos, como Drynariaceae, Grammitidaceae, Gymnogrammitidaceae, Loxogrammaceae, Platyceriaceae e Pleurisoriopsidaceae, de forma que a família
Polypodiaceae no senso Hennipman et al. (1990) corresponde a um grupamento parafilético. Estudos filogenéticos baseados em caracteres moleculares, tais como $r b c L$, atp $A$ e atp $B$, confirmam o parafiletismo da família Polypodiaceae senso Hennipman et al. (1990) (Schuettpelz \& Pryer 2007).

De acordo com Hennipman et al. (1990), a família Polypodiaceae é composta por plantas geralmente terrestres ou epífitas, pequenas (com apenas alguns centímetros) a grandes (ca. $1 \mathrm{~m}$ ou maiores). O caule apresenta simetria dorsiventral e é dictiostélico, geralmente com escamas. As folhas geralmente são articuladas ao caule (com ou sem filopódio), monomorfas ou dimorfas. O pecíolo pode ser cilíndrico ou semicilíndrico, algumas vezes alado, escamoso ou glabro, com muitos feixes vasculares dispostos em $\mathrm{U}$, sendo os mais abaxiais maiores e com feixe de xilema na forma de um gancho. A lâmina pode ser simples, lobada a pinatífida e com costa evidente, 1-pinada ou raramente 2-pinada, peltada, ou decomposta

1. Rua Bom Jesus de Pirapora 2626, 13206-480 Jundiaí, SP, Brasil

2. Instituto de Botânica, Caixa Postal 68041, 04045-972 São Paulo, SP, Brasil

3. Autor para correspondência: dtvasques@gmail.com 
dicotomicamente. Ápice da lâmina com ou sem um segmento terminal, este quando presente, conforme. As escamas do caule possuem morfologia diversa, apresentando uma célula glandular apical, já as escamas das folhas são mais simples. Além das escamas, as folhas também possuem tricomas glandulares. A venação é livre, com nervuras simples ou bifurcadas, ou algumas vezes anastomosadas, com ou sem vênulas inclusas nas aréolas. Os soros não possuem indúsio, e em geral são arredondados, algumas vezes alongados, lineares, ou esporângios acrosticóides (i.e., recobrindo inteiramente a superfície abaxial da lâmina foliar). Os esporângios são curto a longo-pedicelados, o pedicelo é geralmente trisseriado, a cápsula do esporângio pode possuir ou não apêndices, o ânulo é vertical e interrompido pelo pedicelo, o estômio é formado por apenas duas células. Alguns esporângios não funcionais (esporangiásters) podem estar presentes. Em geral, há 64 esporos por esporângio, raramente 8 (em Platycerium ridleyi $\mathrm{H}$. Christ) ou 16 (em Lecanopteris Reinw.), são monoletes, geralmente reniformes, raramente fusiformes, e muito raramente triletes, brancos, amarelos, castanhos ou verdes, com ou sem perisporo proeminente e de vários formatos. Os gametófitos são cordiformes, com um eixo central proeminente e com alas longas. A maioria dos gêneros apresenta número cromossômico $\mathrm{n}=36$ e/ou 37 .

Lellinger (1988) enfatizou que Presl (1836), em sua obra Tentamen Pteridographiae, segregou Campyloneurum devido ao seu padrão de venação "cyrtophleboide" (i.e., as nervuras secundárias são arqueadas para formar aréolas, as quais, geralmente, contêm vênulas livres inclusas). Presl (1836) reconheceu 11 espécies: Campyloneurum lanciforme C. Presl, C. fasciale C. Presl, C. repens (Aubl.) C. Presl, C. phyllitidis (L.) C. Pres1, C. polyanthum C. Presl, C. undulatum C. Presl, C. sieberianum C. Presl, C. costatum C. Presl, C. nitidum C. Presl, C. laevigatum (Cav.) C. Presl e C. decurrens C. Presl. A obra de Presl (1836) foi de extrema importância na história da taxonomia de samambaias, graças a uma maior atenção dada tanto aos caracteres reprodutivos, quanto aos vegetativos, em um contexto em que a maioria dos taxonomistas utilizavam-se apenas de caracteres dos soros e dos esporângios para a classificação (Pichi Sermolli 1973).

Lellinger (1988) reconheceu 50 espécies, sendo que muitas dessas eram reconhecidas como táxons infra-específicos por outros autores. Segundo o autor, dentre os gêneros de Polypodiaceae do Novo Mundo, Campyloneurum é mais relacionado com os gêneros Microgramma C. Presl e Niphidium J. Sm. Ao contrário de outros gêneros em que muitos caracteres da arquitetura e do indumento estão fortemente relacionados, em Campyloneurum, os caracteres mais importantes para a circunscrição das espécies estão nas escamas caulinares, uma vez que as lâminas foliares são, em geral, glabras. Outros caracteres também importantes, segundo Lellinger (1988), são o formato, as dimensões das lâminas e a venação.

Para Hennipman et al. (1990), Campyloneurum C. Presl pertence à subfamília Polypodieae, que é caracterizada por plantas com folhas simples ou, menos comumente, folhas profundamente pinatífidas ou 1-pinadas, raramente mais divididas; exosporo fino ou espesso, mais ou menos verrucoso; perisporo geralmente inconspícuo; escamas caulinares geralmente opacas ou hialinas, ou, algumas vezes, mais ou menos clatradas.

Segundo León (1993a), Campyloneurum é um dos poucos gêneros de Polypodiaceae s. str. restrito ao Neotrópico. Essa autora agrupou as espécies deste gênero em 10 "grupos informais", contendo 47 espécies e quatro variedades. Estes grupos teriam uma origem comum com um ancestral caracterizado por folhas pinatífidas, aréolas primárias não divididas, portando de 2-4 vênulas livres, terrestre e crescendo em locais úmidos a baixas e médias altitudes. León também tratou as espécies com folhas 1-pinadas como pertencentes ao gênero Polypodium (León 1993b). Além disso, a autora chamou a atenção para a presença de muitos indivíduos com características intermediárias em relação às escamas caulinares dentro de uma mesma população, sugerindo que mais estudos são necessários para a validação do valor taxonômico da variação nestes caracteres (León 1993b).

Neste contexto, a circunscrição das espécies (e do próprio gênero) de Campyloneurum tem se mostrado uma questão complicada para os taxonomistas da área. Mickel \& Smith (2004) chamaram a atenção para o fato de que, apesar de existirem tentativas recentes de revisão do gênero (Lellinger 1988; León 1993a), o seu entendimento ainda é incipiente. Assim sendo, trabalhos de revisão do gênero que objetivem o estudo a respeito da circunscrição de suas espécies são ainda muito necessários.

O objetivo deste trabalho foi realizar o levantamento das espécies de Campyloneurum ocorrentes no Estado de São Paulo. 


\section{Material e métodos}

A área de estudo compreendeu o estado de São Paulo, localizado na região sudeste do Brasil, entre os paralelos $20^{\circ}-26^{\circ} \mathrm{S}$ e $44^{\circ}-55^{\circ} \mathrm{W}$, sendo cortado pelo Trópico de Capricórnio e ocupando uma área de aproximadamente $250.000 \mathrm{~km}^{2}$. Tem como limites os estados de Minas Gerais (norte e nordeste), Rio de Janeiro (nordeste), Paraná (sul) e Mato Grosso do Sul (oeste), além do Oceano Atlântico (leste).

A pesquisa bibliográfica foi baseada principalmente nas revisões parciais do gênero Campyloneurum C. Presl realizadas por Lellinger (1988) e por León (1993a), além de trabalhos de Floras regionais recentemente publicados. As propostas de classificação de cada autor foram confrontadas e discutidas, bem como os conceitos de espécies adotadas por eles no gênero.

O estudo foi desenvolvido a partir da análise de material coletado e daqueles depositados nos principais herbários do estado (HRCB, SJRP, SP, SPF, UEC), bem como através da comparação com exsicatas de outros herbários (coleções recentes, históricas e dos tipos nomenclaturais via web) e da análise da literatura disponível.

O tratamento taxonômico é apresentado em ordem alfabética de espécies e, para cada táxon, foram apresentadas descrições, desenhos de suas características diagnósticas, lista de espécimes analisados, bem como mapas de distribuição geográfica e comentários.

As descrições foram feitas a partir de todo o material analisado, sendo que os termos morfológicos utilizados para as descrições seguem o proposto por Stearn (1983) e Lellinger (2002).

Para a abreviação dos nomes dos autores das espécies foi adotado Pichi Sermolli (1996).

As ilustrações foram elaboradas, em estereomicroscópio adaptado com câmara clara no Instituto de Botânica de São Paulo, sendo que foram priorizadas as características diagnósticas de cada espécie.

Os mapas de distribuição geográfica foram feitos com base em informações contidas nas etiquetas dos materiais depositados nos diferentes herbários consultados.

\section{Resultados e Discussão}

Foram reconhecidas nove espécies de Campyloneurum ocorrentes no Estado de São Paulo, com base na análise de caracteres morfológicos. As principais características morfológicas utilizadas para o reconhecimento dessas espécies foram: lâmina foliar, venação e escamas caulinares.

Verificou-se que as escamas caulinares possuem caracteres importantes para o reconhecimento das espécies. Informações tais como: coloração das células das escamas, que pode variar de tonalidades paleáceas até castanho-escuras; iridescência do lúmen dessas células; formato das células que compõem as escamas, que pode variar de arredondado, irregular ou alongado; formato das escamas, que pode variar de arredondado a oval; simetria das aurículas que compõem a base das escamas; forma de inserção das escamas no caule (escamas planas ou buladas); formato do ápice (acuminado até atenuado); e o próprio tamanho das escamas podem ser utilizados com segurança na delimitação em nível específico.

Além disso, as frondes também possuem caracteres interessantes que podem ser utilizados para a delimitação das espécies, tais como: coloração e tamanho dos filopódios (espessamento do pecíolo na base das frondes); distância entre a inserção dos filopódios no caule; coloração e tamanho dos pecíolos; presença de sulcos nos pecíolos; divisão da lâmina, que varia de simples a 1-pinadas; formato da lâmina (linear a lanceolada); formato da base e do ápice foliar; coloração e brilho da lâmina; e o tamanho da lâmina.

Em relação às nervuras da lâmina, são caracteres relevantes: proeminência das nervuras primárias e secundárias sobre a lâmina foliar; presença de divisões das aréolas formadas pelas nervuras secundárias; número de vênulas livres inclusas em cada aréola; e o número de séries de aréolas presentes entre a costa e a margem da lâmina.

Chave de identificação para as espécies de Campyloneurum ocorrentes no Estado de São Paulo

1. Plantas com lâminas 1-pinadas a pinatissectas C. decurrens

1. Plantas com lâminas simples

2. Pecíolo longo (15-20 cm compr.); escamas frequentemente encontradas sobre a costa na face abaxial da lâmina foliar; lâmina foliar não brilhante 
2. Pecíolo curto (menos $15 \mathrm{~cm}$ compr., raramente chegando a $20 \mathrm{~cm}$ compr. em C. fallax); escamas raramente encontradas sobre a costa na face abaxial da lâmina foliar; lâmina foliar brilhante ou não

3. Lâmina estreita, ca. 0,6-0,7 cm larg.; margens foliares revolutas ao longo de toda a lâmina C. angustifolium

3. Lâmina larga, ca. 1,0-6,0 cm larg.; margens foliares não revolutas ao longo de toda a lâmina ou, se revolutas, apenas na base

4. Lâmina verde-amarelada em ambas as faces e brilhante em ambas as faces

5. Caule longo-reptante; filopódios distantes ca. $5 \mathrm{~mm}$ entre si; pecíolo ca. 0,2-0,3 cm larg.; 4 ou 5 aréolas entre a costa e a margem foliar; aréolas não costais não divididas, ou raramente divididas

5. Caule curto-reptante; filopódios distantes no máximo $4 \mathrm{~mm}$ entre si; pecíolo ca. 0,1 cm larg.; 2-3 aréolas entre a costa e a margem foliar; aréolas não costais divididas simetricamente

C. rigidum

4. Lâmina verde-clara a verde-escura em ambas as faces e não brilhante em ambas as faces ou apenas adaxialmente

6. Filopódios esverdeados; escamas do caule castanho-escuras, às vezes acinzentadas; margens foliares às vezes revolutas na base. C. aglaolepis

6. Filopódios castanhos; escamas do caule castanho-claras a castanho-escuras; margens foliares não revolutas

7. Caule robusto (3-4 mm diâm.)

C. nitidum

7. Caule delgado (ca. $2 \mathrm{~mm}$ diâm.)

8. Escamas do caule com células alongadas; filopódios $3 \mathrm{~mm}$ larg.; distantes ca. 3-5 mm entre si; nervuras primárias proeminentes em ambas as faces

8. Escamas do caule com células arredondadas; filopódios $1 \mathrm{~mm}$ larg., distantes, C. repens no máximo, $3 \mathrm{~mm}$ entre si; nervuras primárias mais proeminentes abaxialmente C. lapathifolium

1. Campyloneurum acrocarpon Feé, Crypt. Vasc. Brésil 1: 115, t. 35, f. 3. 1869.

= Campyloneurum wacketii Lellinger, Amer. Fern J. 78: 27. 1988.

Figuras 1-3, 28

Plantas epífitas. Caule curto-reptante, ca. $4 \mathrm{~mm}$ diâm., com escamas castanho-escuras, clatradas, ovais, base auriculada, aurículas simétricas, ápice acuminado, ca. $1,5 \times 1 \mathrm{~mm}$, células arredondadas. Frondes 45-55 cm compr., monomorfas; filopódios 2,5-3 $\times 1-1,5 \mathrm{~mm}$, distantes ca. $1 \mathrm{~cm}$ entre si; pecíolo $15-20 \times 0,2 \mathrm{~cm}$, paleáceo, glabro, alado, sulcado adaxialmente; lâmina ca. $35 \times 5 \mathrm{~cm}$, simples, lanceolada, cartácea, não brilhante em ambas as faces no tecido laminar, glabra, escamas semelhantes às do caule presentes sobre a costa na face abaxial da lâmina; nervuras anastomosadas, 7 aréolas não divididas entre a costa e a margem da lâmina, aréolas adjacentes à costa portando uma única vênula livre, as demais aréolas portando duas vênulas livres, nervuras primárias paleáceas, nervuras secundárias obscuras em ambas as faces da lâmina. Soros em 7 séries de fileiras entre a costa e a margem, apenas 1 soro em cada aréola adjacente à costa, 2 soros nas demais aréolas.

Material examinado: BRASIL. São PAULO: São Paulo, Ipiranga, 1912, H. Luederwaldt s.n. (SP24188); São Sebastião, Parque Estadual Serra do Mar, 20-IV-2000, A. Salino et al. 5328 (SPF); Cananéia, Ilha do Cardoso, 20-VI-2002, T.B. Breier \& R.B. Singer $175 b$ (UEC); Sete Barras, Parque Estadual Carlos Botelho, 25-VIII-2002, T.B. Breier \& J.C. Budke 567 (UEC); idem, 27-IX-2002, T.B. Breier \& V.A.O. Dittrich 670 (UEC); Campinas, Reserva Florestal Santa Genebra, 13-II-1992, A. Salino 1277 (UEC); idem, 16-III-1992, A. Salino 1315 (UEC); Ubatuba, Parque Estadual da Serra do Mar, 6-VIII-1988, J.E.L.S. Ribeiro et al. 435 (HRCB); idem, núcleo Picinguaba, 5-XII-1991, A. Salino 1221 a (UEC); idem, núcleo Poruba, 11-XI-1993, A. Salino 1880 (HRCB); idem, 
3-XII-2000, V.A.O. Dittrich \& K.A. Ressel 785 (HRCB); idem, núcleo Picinguaba, 16-V-2006, L.F. Mania 1 (HRCB).

Campyloneurum acrocarpon pode ser reconhecida pelo seu pecíolo longo (15-20 cm compr.) e pela presença de escamas semelhantes às do caule sobre a costa, na face abaxial da lâmina foliar.

Esta espécie apresenta distribuição restrita à faixa leste do estado, chegando até o interior, na região de Campinas (figura 28).

León (1993a) sinonimizou Campyloneurum wacketii Lellinger, sob $C$. acrocarpon. Esta sinomização também é seguida no presente estudo, devido à similaridade da descrição apresentada por Lellinger (1988) com o observado nos espécimes analisados neste trabalho.

2. Campyloneurum aglaolepis (Alston) de la Sota, Opera Lilloana 5: 96. $1960 \equiv$ Polypodium aglaolepis Alston, J. Bot. 77: 346. 1939.

Figuras 4-6, 28

Plantas epífitas. Caule curto-reptante, ca. $4 \mathrm{~mm}$ diâm., com escamas castanho-acinzentadas, clatradas, ovais, base auriculada, aurículas simétricas, ápice atenuado, ca. $4 \times 1 \mathrm{~mm}$, com células alongadas. Frondes 30-60 cm compr., monomorfas; filopódios esverdeados, $2 \times 1,5 \mathrm{~mm}$, muito próximos entre si; pecíolo 1-2 $\times 0,1-0,2 \mathrm{~cm}$, paleáceo, glabro, alado, sulcado adaxialmente; lâmina 30-60 × 1-2 cm, linear, subcoriácea, simples, glabra e não brilhante em ambas as faces, verde-clara, margem às vezes revoluta próxima à base da lâmina, ápice cuspidado; nervuras anastomosadas, 2 ou 3 séries de aréolas simetricamente divididas entre a costa e a margem da lâmina, obscuras em ambas as faces da lâmina, portando 1 única vênula inclusa em cada. Soros em 2 ou 3 fileiras entre a costa e a margem da lâmina, 1 soro por aréola.

Material examinado: BRASIL. S̃̃o PAulo: Brotas, 22-V-1993, C.E. Rodrigues Jr. \& M.R. Silva 458 (SP, SJRP); Bauru, Jardim Botânico Municipal de Bauru, 21-VII-2005, G.A. Nóbrega \& M. Andrade 107 (SP); Itirapina, Serra do Itaqueri, 8-IX-1991, A. Salino 1086 (UEC); Botucatu, Cachoeira da Marta, 22-XI-1997, E.F. Santos \& G.Q. Cordeiro 11 (SJRP).

Esta espécie pode ser facilmente identificada pelos seus filopódios esverdeados, pelas escamas caulinares castanho-acizentadas e com células alongadas, e pela lâmina foliar linear.
A sua distribuição é restrita a regiões mais centrais do estado, onde existem florestas mais secas que na região litorânea (figura 28).

3. Campyloneurum angustifolium (Sw.) Fée, Mém. Foug. 5: 257. 1852 E Polypodium angustifolium Sw., Prodr. 130. 1788.

Figuras 7-9, 29

Plantas epífitas. Caule longo-reptante, ca. $2 \mathrm{~mm}$ diâm., com escamas castanho-claras, clatradas, ovais, base auriculada, aurículas simétricas, ápice atenuado, ca. $2,5 \times 1 \mathrm{~mm}$, células alongadas, com lúmen iridescente e parede castanho-clara. Frondes $30-40 \mathrm{~cm}$ compr., monomorfas; filopódios $1,5 \times 1 \mathrm{~mm}$, distantes ca. $3 \mathrm{~mm}$ entre si; pecíolo $1 \times 0,1 \mathrm{~cm}$, paleáceo, glabro, alado; lâmina 30-40 × 0,6-0,7 cm, simples, linear, cartácea, glabra e não brilhante em ambas as faces, verde-clara, margens revolutas ao longo da lâmina; nervuras anastomosadas, obscuras, 1 a 3 séries de aréolas entre a costa e a margem foliar, 1 vênula livre por aréola, obscuras em ambas as faces da lâmina. Soros em 1 a 3 fileiras entre a costa e a margem da lâmina, 1 soro por aréola.

Material examinado: BRASIL. SÃo PAULO: Bragança, VIII-1910, C. Duarte s.n. (SP7842); Serra Negra, 6-VI-1927, F.C. Hoehne s.n. (SP20710); idem, 7-VI-1927, F.C. Hoehne s.n. (SP20695); São Carlos, 22-VI-1961, G. Eiten et al. 3133 (SP); idem, s.d., A. Loefgren s.n. (SP21993); Campos do Jordão, 14-IX-1923, F.C. Hoehne s.n. (SP8697); idem, Horto Florestal, 17-XII-1966, J. Mattos \& N. Mattos 14476 (SP); idem, 28-IX-1976, P.H. Davis et al. 2953 (UEC); idem, Reserva do Instituto Florestal, 30-IX-1976, P.H. Davis et al. 3110 (UEC); idem, 20-XI-1980, P.G. Windisch 2950 (SJRP); idem, Parque Estadual de Campos do Jordão, 1-X-1988, A. Salino 562 (UEC); idem, 5-I-1990, L. Amorim 10 (SJRP); idem, 21-III-1996, J. Prado \& M.P. Marcelli 799 (SP); idem, 22-III-1996, J. Prado \& M.P. Marcelli 835 (SP); idem, 22-III-1996, J. Prado \& M.P. Marcelli 819 (SP); Itirapina, Serra do Itaqueri, 23-VII-1991, A. Salino 989 (UEC); São José do Barreiro, Serra da Bocaina, 29-V-1958, O. Handro 787 (SP); Amparo, Monte Alegre, 30-III-1943, M. Kuhlmann 474 (SP); Mogi Guaçu, Reserva Florestal, s.d., Tamandaré \& A.C. Brade 6521 (SP); Rio Feio, XII-1905, G. Edwall s.n. (SP21990); Barretos, XII-1911, C. Duarte 9 (SP); Bananal, 26-IX-1978, A.T. Silva 118 (SP); Brotas, Mata do 


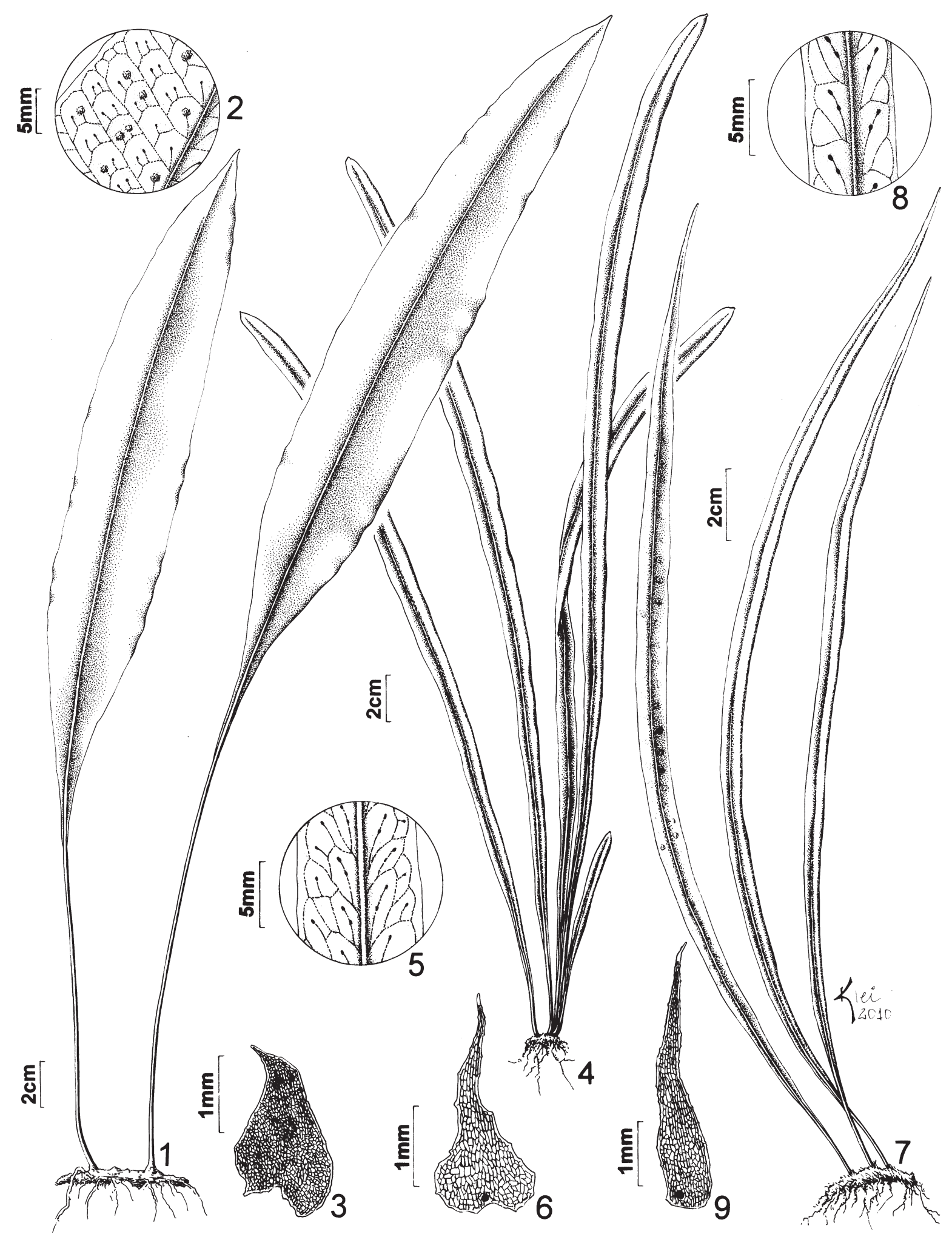

Figuras 1-9. Espécies de Campyloneurum do Estado de São Paulo. 1-3. Campyloneurum acrocarpon (Luederwaldt s.n., SP24188). 1. Hábito. 2. Detalhe das nervuras. 3. Detalhe da escama do caule. 4-6. C. aglaolepis (Nóbrega \& Andrade 107, SP). 4. Hábito; 5. Detalhe das nervuras. 6. Detalhe da escama do caule. 7-9. C. angustifolium (Hoehne s.n., SP20710). 7. Hábito. 8. Detalhe das nervuras. 9. Detalhe da escama do caule.

Figures 1-9. Species of Campyloneurum of the state of São Paulo. 1-3. Campyloneurum acrocarpon (Luederwaldt s.n., SP24188). 1. Habit. 2. Detail of the veins. 3. Detail of stem scale. 4-6. C. aglaolepis (Nóbrega \& Andrade 107, SP). 4. Habit; 5. Detail of the veins. 6. Detail of stem scale. 7-9. C. angustifolium (Hoehne s.n., SP20710). 7. Habit. 8. Detail of the veins. 9. Detail of stem scale. 
Viveiro Municipal, 8-IX-1991, A. Salino 1053 (UEC); idem, Vila de São Sebastião da Serra, 27-I-2007, S.A. Nicolau et al. 3163 (SP); Espírito Santo do Pinhal, Fazenda Palmeira, 29-XII-1987, A. Salino 260 (UEC); Atibaia, Pedra Grande, 4-V-1987, L.C. Bernacci et al. 19658 (UEC); idem, Pedra Grande, Fazenda Grota Funda, 4-V-1987, L.C. Bernacci et al. 19658 (SJRP); Botucatu, 22-XI-1997, E.F. Santos et al. 14 (SJRP); Campos da Bocaina, Serra do Mar, 4-III-1992, P.G. Windisch 6840 (SJRP).

Campyloneurum angustifolium corresponde a uma espécie comumente confundida com outras espécies de Campyloneurum, como C. austrobrasilianum de la Sota e C. aglaolepis. Basicamente, estas espécies são distinguidas por caracteres das escamas caulinares. C. angustifolium possui escamas caulinares com duas aurículas simétricas na base, enquanto que C. austrobrasilianum, segundo León (1993), possui escamas caulinares com bases formadas por duas aurículas assimétricas. Além disso, as escamas caulinares de $C$. angustifolium são maiores (5-6 mm compr. e com mais de $1 \mathrm{~mm}$ larg.) que em C. austrobrasilianum (2,5-4,5 mm compr. e 0,3-0,8(-1) mm larg.). As paredes celulares das escamas de $C$. angustifolium são castanhoescuras e possuem lúmen iridescente. Exemplares de C. austrobrasilianum não foram observados no estado de São Paulo.

Campyloneurum angustifolium pode ser encontrada, no estado de São Paulo, desde o extremo leste (i.e., município de Bananal), até alguns municípios do noroeste (i.e., Barretos) (figura 29).

4. Campyloneurum decurrens C. Pres1, Tent. Pterid.: 190. 1836.

Figuras 10-12, 29

Plantas terrestres. Caule curto-reptante, ca. $1 \mathrm{~cm}$ diâm., com escamas castanho-escuras, clatradas, ovais, base auriculada, aurículas simétricas, ápice acuminado, ca. 1-1,2 $\mathrm{mm} \times 5-6 \mathrm{~mm}$, abundantes, células alongadas, com lúmen iridescente e parede castanho-escura. Frondes 30-90 cm compr., monomorfas; filopódios $1 \times 1 \mathrm{~cm}$, distantes ca. $1 \mathrm{~cm}$ entre si; pecíolo 15-60 × 0,2-0,6 cm, robusto, glabro; lâmina 1-pinada na base a pinatissecta no ápice, cartácea, glabra e não brilhante em ambas as faces; pinas proximais sésseis e distais decorrentes, lanceoladas, ca. 5 vezes mais compridas do que largas; nervuras anastomosadas visíveis, 5 a 7 séries de aréolas entre a costa e a margem da lâmina, aréolas não divididas, 1 vênula livre em cada aréola adjacente à costa, 2(ou 3) vênulas livres nas demais aréolas, venação paleácea visível e proeminente em ambas as faces da lâmina. Soros 5 a 7 fileiras entre a costa e a margem da lâmina, 2 soros por aréola.

Material examinado: BRASIL. São PaUlo: Santo André, Estação Alto da Serra, VI-1910, H. Luederwaldt s.n. (SP21929); Ubatuba, Ilha Anchieta, 7-VI-2000, F.P.F. Athayde 640 (SJRP, SP); idem, 18-II-2004, J. Prado et al. 1512 (SP); idem, Parque Estadual Serra do Mar, núcleo Picinguaba, 9-XI-1993, A. Salino 1831 (HRCB); idem, Instituto Oceanográfico, VII-1960, I.M. Válio 84 (SPF); São Sebastião, Praia de Baraqueçaba, 12-X-1985, P.G. Windisch et al. 4650 (SJRP); Tanabi, Fazenda São Dimas, 23-I-2003, F.P.F. Athayde et al. 1149 (SJRP).

Campyloneurum decurrens é a única espécie deste gênero com folhas compostas e que ocorre no Brasil. Além das folhas 1-pinadas a pinatífidas, a espécie também pode ser distinguida por suas pinas distais decorrentes, característica esta que deu origem ao nome da espécie.

A ocorrência desta espécie no estado é bastante restrita, podendo ser encontrada em alguns municípios do litoral norte do estado, no município de São Paulo e na região do município de Tanabi, no norte do estado (figura 29).

5. Campyloneurum fallax Fée, Crypt. Vasc. Brésil 1: 114, t. 35, f. 2.1869.

Figuras 13-15, 30

Plantas epífitas. Caule longo-reptante, ca. $5 \mathrm{~mm}$ diâm., com escamas castanho-claras, abundantes, clatradas, orbiculares a ovais, base auriculada, aurículas simétricas, ápice arredondado a acuminado, ca. $5 \times$ $4 \mathrm{~mm}$, células arredondadas, com lúmen castanhoclaro e parede celular delgada. Frondes $15-45 \mathrm{~cm}$ compr., monomorfas; filopódios $2,5 \times 2,5 \mathrm{~mm}$, distantes ca. $5 \mathrm{~mm}$ entre si; pecíolo 5-20 $\times 0,2-0,3 \mathrm{~cm}$, castanhoclaro, robusto, glabro, alado, sulcado adaxialmente; lâmina 15-35 × 1,5-3 cm, simples, lanceolada, subcoriácea, glabra em ambas as faces, verde-amarelada, brilhante em ambas as faces; nervuras anastomosadas, 4(ou 5) aréolas entre a costa e a margem da lâmina, aréolas adjacentes a costa portando 1 vênula livre, as demais aréolas não divididas e portando 2 vênulas livres, ou raramente divididas, obscuras em ambas as faces da lâmina. Soros 4(ou 5) fileiras entre a costa e a margem da lâmina, 1 soro nas aréolas adjacentes à costa, 2 soros nas demais aréolas. 
Material examinado: BRASIL. São PAULO: São José do Barreiro, Serra da Bocaina, 29-V-1958, O. Handro 785 (SP, SPF); São Paulo, Jaraguá, II-1912, H. Luederwaldt s.n. (SP24187); Campos do Jordão, Fazenda da Guarda, 26-VII-1967, J. Mattos \& N. Mattos 15014 (SP).

Campyloneurum fallax é facilmente reconhecida por sua lâmina foliar verde-amarelada e brilhante, glabra em ambas as faces, além de seu caule robusto, com mais de $4 \mathrm{~mm}$ de diâmetro, portando escamas grandes, com lúmen das células castanho-claro e paredes delgadas.

Há registros desta espécie apenas nas regiões mais litorâneas do estado de São Paulo, havendo, no entanto, poucos registros de coleta nos herbários visitados (figura 30).

6. Campyloneurum lapathifolium (Poir.) Ching, Sunyatsenia 5: 263. $1940 \equiv$ Polypodium lapathifolium Poir., Encycl. 5: 514. 1804.

Figuras 16-18, 30

Plantas epífitas. Caule longo-reptante, ca. $1 \mathrm{~mm}$ diâm., com escamas castanho-escuras, concentradas próximo aos filopódios, clatradas, ovais, base auriculada, aurículas simétricas, ápice atenuado, ca. 2-3 × 0,5-0,8 mm, células arredondadas, com lúmen iridescente e parede escura. Frondes $15-35 \mathrm{~cm}$ compr., monomorfas; filopódios ca. 1,5 × $1 \mathrm{~mm}$, distantes ca. $3 \mathrm{~mm}$ entre si; pecíolo 1,5-6 × 0,1-0,2 cm, paleáceo, glabro, alado, com sulco adaxial contínuo pela costa laminar; lâmina 15-30 × 1-2,5 cm, simples, lanceolada, membranácea a cartácea, glabra e não brilhante em ambas as faces, às vezes com ápice dividido; nervuras anastomosadas, 4 a 7 séries de aréolas não divididas entre a costa e a margem da lâmina, aréolas adjacentes à costa portando uma única vênula livre, demais aréolas portando 2 vênulas livres, nervuras primárias paleáceas abaxialmente e obscuras adaxialmente, nervuras secundárias obscuras em ambas as faces. Soros em 4 a 7 fileiras entre a costa e a margem da lâmina, 1 soro em cada aréola adjacente à costa, 2 soros nas demais aréolas.

Material examinado: BRASIL. São Paulo: Santo André, Estação Alto da Serra, 23-VIII-1904, G. Edwall \& A. Puttemans s.n. (SP7839); idem, Parque Cajurú, VI-1910, H. Luederwaldt s.n. (SP7836); idem, 20-V-1920, F.C. Hoehne s.n. (SP24190); idem, 10-VI-1922, H. Luederwaldt s.n. (SP22080); idem, 4-X-1956, O. Handro 634 (SP,
SPF); idem, 15-VII-1963, C.P. Lima \& L. Zimmermann 9 (SP); Iguape, Reserva Ecológica Juréia-Itatins, 15-VIII-1990, J. Prado et al. 339 (SP); idem, 26-VII-1991, E.A. Anunciação \& S. A. Nicolau 93 (SP); Cunha, Parque Estadual da Serra do Mar, 22-VI-2006, M.C.H. Mamede et al. 676 (SP); Alpes Marítimos, s.d., M. Wacket s.n. (SP22082); Caraguatatuba, Estação da Reserva Florestal, 20-V-1961, G. Eiten \& L.T. Eiten 2840 (SP); Ubatuba, Instituto Oceanográfico, VII-1960, I.M. Válio 100 (SP); idem, Parque Estadual da Serra do Mar, núcleo Picinguaba, 9-XI-1993, A. Salino 1830 (HRCB); Juquitiba, Fazenda Itereí, 21-XI-1994, J. Prado et al. 525 (SP); Cananéia, 6-IV-1978, A.T. Silva 96 (SP); Pindorama, 15-IV-1994, V.C. Souza et al. 5741 (SP); Peruíbe, Estação Ecológica JuréiaItatins, 13-VI-1969, P.G. Windisch 25 (SJRP); idem, 11-X-1988, R. Simão-Bianchini 57 (SPF); Itirapina, Serra do Itaqueri, 23-VII-1991, A. Salino $988 b$ (UEC); idem, IX-1991, A. Salino 1085 (UEC); São Miguel Arcanjo, Parque Estadual de Carlos Botelho, 25-IV-2002, R.G. Udulutsch et al. 723 (UEC); idem, 25-IV-2002, R.G. Udulutsch et al. 726 (UEC); Sete Barras, Parque Estadual Carlos Botelho, 5-VI-1992, J.A. Lombardi 118 (UEC); idem, 27-V-2002, T.B. Breier \& M.A.R. Andrade 145 (UEC); idem,17-VIII-2002, T.B. Breier \& J.C. Budke 420 (UEC); idem, 17-VIII-2002, T.B. Breier \& J.C. Budke 421 (UEC); idem, 29-IX-2002, V.A.O. Dittrich \& T.B. Breier 1187 (HRCB); idem, 29-IX-2002, V.A.O. Dittrich \& T.B. Breier 1251 (HRCB); Capão Bonito, Fazenda Intervales, 30-X-1991, A. Salino 1155 (UEC); idem, 30-X-1991, A. Salino 1174 (UEC); Zacarias, 24-V-2001, D.F. Peralta 952 (SJRP).

Campyloneurum lapathifolium é comumente confundida com C. repens (Aubl.) C. Presl. No entanto, enquanto $C$. lapathifolium é caracterizada pelo seu caule delgado (ca. $1 \mathrm{~mm}$ larg.), portando filopódios com ca. $1 \mathrm{~mm}$ de largura, C. repens é caracterizada por possuir um caule menos delgado (ca. $2 \mathrm{~mm}$ larg.), portando filopódios com ca. $3 \mathrm{~mm}$ de largura.

Esta espécie pode ser reconhecida pelas suas lâminas foliares lanceoladas, muito aproximadas. O caule é bastante delicado, com ca. $1 \mathrm{~mm}$ de diâmetro e as nervuras primárias da lâmina proeminentes apenas abaxialmente, formando um ângulo maior que $60^{\circ} \mathrm{com}$ a costa. Além disso, os soros são pequenos (ca. $0,5 \mathrm{~mm}$ ) e muito numerosos. 


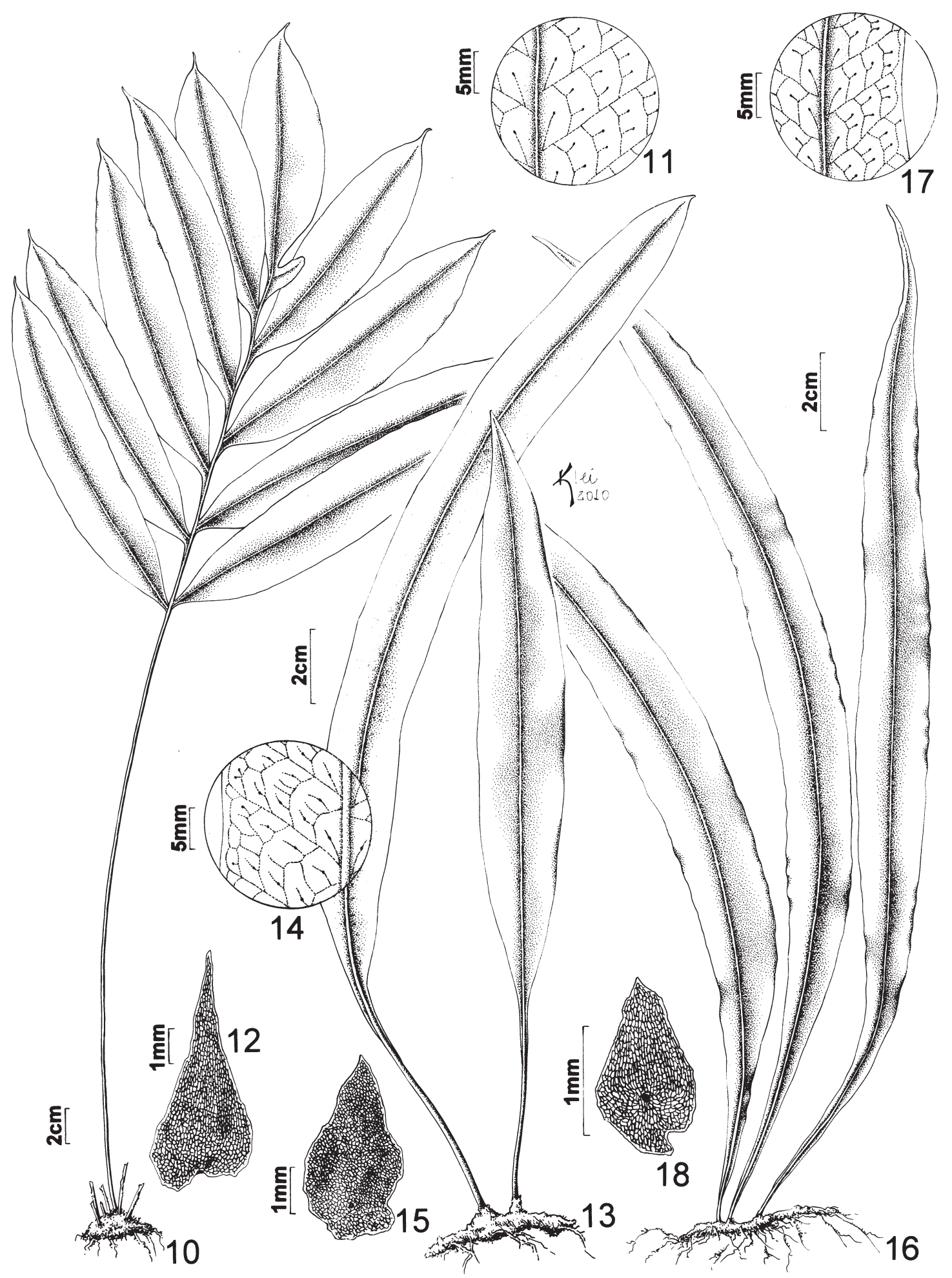

Figuras 10-18. Espécies de Campyloneurum do Estado de São Paulo. 10-12. Campyloneurum decurrens (Luederwaldt s.n., SP21929). 10. Hábito. 11. Detalhe das nervuras. 12. Detalhe da escama do caule. 13-15. C. fallax (13 e 15. Mattos \& Mattos 15014, SP. 14. Luederwaldt s.n., SP24187). 13. Hábito. 14. Detalhe das nervuras. 15. Detalhe da escama do caule. 16-18. C. lapathifolium (Válio 100, SP). 16. Hábito. 17. Detalhe das nervuras. 18. Detalhe da escama do caule.

Figures 10-18. Species of Campyloneurum of the state of São Paulo. 10-12. Campyloneurum decurrens (Luederwaldt s.n., SP21929). 10. Habit. 11. Detail of the veins. 12. Detail of stem scale. 13-15. C. fallax (13 e 15. Mattos \& Mattos 15014, SP. 14. Luederwaldt s.n., SP24187). 13. Habit. 14. Detail of the veins. 15. Detail of stem scale. 16-18. C. lapathifolium (Válio 100, SP). 16. Habit. 17. Detail of the veins. 18. Detail of stem scale. 
A distribuição da espécie no estado é predominantemente na região sudeste, com uma ocorrência no município de Zacarias, na região oeste do estado (figura 30 ).

7. Campyloneurum nitidum (Kaulf.) C. Presl, Tent. Pterid. 190. $1836 \equiv$ Polypodium nitidum Kaulf., Enum. Filic.: 92. 1824.

Figuras 19-21, 31

Plantas epífitas ou terrestres. Caule longoreptante, ca. 3-4 mm diâm., com escamas abundantes, castanho-claras, clatradas, orbiculares a ovais, base auriculada, aurículas simétricas, ápice arredondado a agudo, ca. 2,5 $\times 2 \mathrm{~mm}$, células arredondadas. Frondes 30-90 cm compr., monomorfas; filopódios ca. $3 \times 4 \mathrm{~mm}$, distantes cerca de 7-10 mm entre si; pecíolo 3-8 $\times$ 0,3 cm, castanho-claro, glabro, robusto, alado; lâmina 30-80 × 2-6 cm, simples, lanceolada, cartácea, glabra em ambas as faces, brilhante adaxialmente; nervuras anastomosadas, 6 a 10 séries de aréolas entre a costa e a margem foliar, aréolas não costais não divididas, 2 vênulas livres por aréola, venação primária conspícua e venação secundária obscura em ambas as faces da lâmina, presença de uma única aréola junto à margem foliar. Soros 6 a 10 fileiras entre a costa e a margem da lâmina, 2 soros por aréola.

Material examinado: BRASIL. SÃo Paulo: MogiGuaçu, Reserva-Florestal, 22-XII-1965, J. Mattos 13179 (SP); idem, Reserva Biológica, 2-X-1985, L.M. Esteves 104 (SJRP, UEC); idem, 7-VI-1989, E.A. Simabukuro 2 (UEC); idem, 8-XI-1989, E.A. Simabukuro 51 (UEC); São José do Rio Pardo, IX-1989, H. Loefgren s.n. (SP21908); São José do Barreiro, 1-V-1926, F.C. Hoehne s.n. (SP17695); Conceição de Itanhaém, 23-X-1891, A. Loefgren s.n. (SP24189); Santo Amaro, 3-IX-1942, L. Roth 194 (SP); São Paulo, Butantã, 22-V-1917, F.C. Hoehne s.n. (SP144); idem, Butantã, Reserva da Cidade Universitária Armando Sales Oliveira (CUASO), 22-IV-1976, R.C. Mendonça et al. s.n. (SPF); idem, Butantã, Reserva da CUASO, 13-V-1993, R. Dislich 3 (SPF); idem, Butantã, Reserva da CUASO, 17-V-1994, R. Dislich 94 (SPF); idem, Butantã, Reserva da CUASO, 22-VIII-1994, R. Dislich 97 (SPF); idem, Butantã, Reserva da CUASO, 19-X-1995, M. Groppo Jr. 72 (SPF); idem, Butantã, Reserva da CUASO, 16-II-1996, M. Groppo Jr. 121 (SPF); idem, Butantã, Reserva da CUASO, 17-X-1996, M. Groppo Jr. 237 (SP, SPF); idem, Jaraguá, II-1912, H. Luederwaldt s.n. (SP22113); idem, Jaraguá, 23-VIII-1959, I.M. Válio s.n. (SP82973); idem, Pinheiros, 11-II-1906, A. Usteri s.n. (SP21967); idem, Jardim Botânico, 13-VII-1970, G. Eiten et al. 2086 (SP); idem, Jardim Botânico, 10-X-1973, O. Handro 2231 (SP); idem, Jardim Botânico, 3-VI-1974, O. Handro 2260 (SP); idem, Jardim Botânico, 8-VIII-1979, A. Custodio Filho 127 (SP); idem, Cidade Jardim, X-1940, W. Hoehne 594 (SPF); idem, Reserva do Instituto de Botânica, 2-IX-1976, P.H. Davis et al. 60457 (UEC); Bauru, Jardim Botânico Municipal, 21-VI-2004, G.A. Nóbrega \& M. Andrade 83 (SP); idem, Jardim Botânico Municipal, 21-VII-2005, G.A. Nóbrega \& M. Andrade 106 (SP); idem, Reserva da UNESP, 31-V-2006, M. Carboni et al. 421 (SP); Juqueri, X-1901, Hammar s.n. (SP22109); Amparo, Monte Alegre, 30-VIII-1943, M. Kuhlmann 1043 (SP); Mairiporã, Serra da Cantareira, 28-VI-1919, F.C. Hoehne s.n. (SP3376); idem, Parque Estadual da Cantareira, Núcleo Águas Claras, 7-VI-2005, M.C. Gobitta et al. 11 (SP); São Carlos, Fazenda Canchim, 22-VI-1961, G. Eiten et al. 3132 (SP); idem, 26-IX-1997, M.R. Pietrobom-Silva 4185 (SPF); Tapiraí, 11-V-1994, R. Mello-Silva et al. 903 (SPF); idem, 8-XI-2003, R. Mello-Silva et al. 2178 (SP, SPF); Pindamonhangaba, 29-XI-1993, S.A. Nicolau et al. 656 (SP); Bragança, VIII-1910, Duarte 24 (SP); Teodoro Sampaio, Parque Estadual Morro do Diabo, 13-I-1995, M.R. Silva 1537A (SPF); idem, Parque Estadual Morro do Diabo, 16-I-1995, M.R. Silva 1583 (SPF); idem, Parque Estadual Morro do Diabo, 17-I-1995, M.R. Silva 1624 (SPF); Jaci, 13-IX-1992, M.R. Silva 427 (SPF); Estrela do Norte, 25-VII-1997, M.R. Pietrobom-Silva 4030 (SPF); Borborema, 21-XII-1996, M.R. Pietrobom-Silva 3933 (SPF); idem, 21-XII-1996, M.R. Pietrobom-Silva 3906 (SJRP); Zacarias, 1-VI-1995, F.R. Nonato et al. 109 (SPF); idem, 19-XI-1999, D.F. Peralta \& F.R. Nonato 616 (SJRP); Santo André, Paranapiacaba, 16-VII-1963, O. Handro 1067 (SPF); idem, IX-1967, O. Handro 1213 (SPF); idem, 3-IX-1976, P.H. Davis et al. 60501 (UEC); Bragança Paulista, 6-X-1990, R. Mello-Silva et al. 373 (SPF); Caraguatatuba, 3-XII-2000, P. Fiaschi et al. 489 (SPF); Sete Barras, Parque Estadual Carlos Botelho, 6-VI-1992, J.A. Lombardi 117 (UEC); idem, Fazenda Intervales, 21-VII-1994, A. Salino 2043 (UEC); idem, 14-IX-2000, V.P. Zipparro 2002 (HRCB); idem, 13-XII-2000, V.A.O. Dittrich \& C. Von Allmen 817 (HRCB); idem, 13-XI-2001, V.A.O. Dittrich 1024 
(HRCB); idem, Parque Estadual Carlos Botelho, 27-IX-2002, V.A.O. Dittrich \& T.B. Breier 1205 (HRCB); Itirapina, Serra do Itaqueri, 23-VII-1991, A. Salino 988 a (UEC); Brotas, Mata do Viveiro Municipal, 14-VII-1991, A. Salino 938 (HRCB, UEC); Campos do Jordão, Reserva do Instituto Florestal, 29-IX-1976, P.H. Davis et al. 3066 (UEC); Cananéia, Ilha da Casca, 8-IX-1976, P.H. Davis et al. 60702 (UEC); idem, 8-IX-1976, P.H. Davis 60730 et al. (UEC); Iguape, 6-IX-1976, P.H. Davis et al. 60540 (UEC); Mirassol, Mata da Grota, 6-VII-1987, A. Salino 219a (UEC); Espírito Santo do Pinhal, Fazenda Palmeiras, 29-XII-1987, A. Salino 253 (UEC); Ubatuba, Parque Estadual Serra do Mar, núcleo Picinguaba, 8-X-1988, M.M.L. Cunha et al. 112 (HRCB); idem, 10-XII-1989, A. Furlan et al. 1098 (HRCB); idem, Parque Estadual da Serra do Mar, 30-I-1996, A. Salino 2446 (UEC); idem, Parque Estadual da Serra do Mar, 3-II-1996, A. Salino 2505 (UEC); idem, Parque Estadual da Ilha Anchieta, 7-VI-2000, V.S. Pereira 36 (SJRP); idem, Parque Estadual da Ilha Anchieta, 1-I-2001, F.P.F. Athayde et al. 899 (SJRP); Analândia, Serra do Cuscuzeiro, 8-IX-1987, A. Salino 135 (SJRP); Colina, Fazenda Couelaria Paulista, 26-VIII-1990, E.D. Castellani 93 (SJRP); Planalto, 15-VIII-1996, M.R. PietrobomSilva \& F.M. Pedro 3429 (SJRP); Nova Itapirema, 9-IV-1988, F. Sossai 21 (SJRP); Monte Azul Paulista, 5-V-2000, A. Matavelli 77 (SJRP); Ubarana, Fazenda Santa Palmira, 18-V-2000, F.P.F. Athayde et al. 571 (SJRP); idem, Fazenda Paulo Teixeira, 31-V-2000, F.P.F. Athayde et al. 609 (SJRP); Jundiaí, Reserva Biológica Municipal da Serra do Japi, 19-V-2007, J.A. Lombardi et al. 6662 (HRCB); idem, 22-X-2007, J.A. Lombardi \& S.M. Hieda 6936 (HRCB).

Campyloneurum nitidum pode ser facilmente distinguida de $C$. repens pelo seu caule mais largo (de 3 a 4 mm de diâmetro vs. ca. 2 mm). Esta espécie apresenta grande variação morfológica, sendo que os tamanhos da lâmina foliar e dos pecíolos variam muito entre os espécimes. Em geral, são plantas com lâminas foliares grandes, apresentando grande variação no tamanho dos pecíolos e com escamas arredondadas sobre o caule. As exsicatas analisadas e previamente identificadas como C. phyllitidis (L.) C. Presl e como C. major (Hieron. ex Hicken) Lellinger foram redeterminadas como $C$. nitidum. No caso de C. phyllitidis, a espécie não ocorre na região sudeste do país. Já no caso de C. major, verificou-se que o tipo de Polypodium nitidium, descrito por Kaulfuss
(1824) é semelhante aos exemplares determinados como C. major. Assim sendo, C. major passa ser sinônimo de $C$. nitidum, sendo que este nome é o mais antigo para este táxon.

Campyloneurum nitidum apresenta distribuição ampla pelo estado de São Paulo, ocorrendo desde regiões litorâneas, até o extremo ocidente do estado (figura 31).

8. Campyloneurum repens (Aubl.) C. Presl, Tent. Pterid.: 190. $1836 \equiv$ Polypodium repens Aubl., Hist. Pl. Guiane 2: 962.1775.

Figura 22-24, 32

Plantas epífitas. Caule longo-reptante, ca. $2 \mathrm{~mm}$ diâm., com escamas abundantes, castanho-escuras e fortemente clatradas, ovais, base auriculada, aurículas simétricas, ápice atenuado, ca. 2-2,5 × 0,5-1 mm, células alongadas e iridescentes. Frondes $30-50 \mathrm{~cm}$ compr., monomorfas, muito próximas entre si; filopódios ca. $2 \times 3 \mathrm{~mm}$, distantes cerca de 3-5 mm entre si; pecíolo 3-5 × 0,15-0,2 cm, castanho-claro, glabro, alado; lâmina 20-30 × 2-4 cm, simples, lanceolada, cartácea, glabra e não brilhante em ambas as faces; nervuras anastomosadas, 6 a 9 séries de aréolas entre a costa e a margem foliar, aréolas não costais não divididas, 2 vênulas livres por aréola, venação primária conspícua e venação secundária obscura em ambas as faces da lâmina. Soros 6 a 9 fileiras entre a costa e a margem da lâmina, 1 ou 2 soros por aréola.

Material examinado: BRASIL. São PAULo: Serra da Cantareira, VI-1913, F. Tamandaré \& A.C. Brade 6546 (SP); idem, 18-VI-1960, G. Eiten et al. 2180. (SP); Iguape, 6-IX-1976, P.H. Davis et al. 60540 (SP); idem, 21-IX-1990, S.J.G. Silva et al. 72 (SP); idem, 11-VI-1991, M.A. Carvalhaes et al. 40 (SP); idem, 21-IX-1991, I. Fernandes et al. 1009 (SP); Cunha, Reserva Florestal, 11-14-II-1981, A. Custodio Filho 528 (SP); idem, Parque Estadual da Serra do Mar, 19-III-1996, C.B. Costa et al. 166 (SP); Cássia dos Coqueiros, 10-II-1997, F.P.F. Athayde 123 (SP, SPF, UEC); Casa Grande, 20-VIII-1978, M. Kirizawa 222 (SP); Santos, Ilha das Flores, VI-1914, H. Luederwaldt S.n. (SP22039); Boa Esperança do Sul, 7-VII-1964, J.C. Gomes Jr. 2050 (SP); Zacarias, 13-VIII-1994, M.R. Silva \& F.R. Nonato 1354 (SJRP, SPF); idem, Fazenda Santa Irene, 1-VI-1995, F.R. Nonato et al. 109 (SJRP); Cananéia, Ilha Comprida, 25-II-1983, J.R. Pirani \& O. Yano 544 (SPF); Campinas, Reserva Florestal Santa Genebra, 
11-III-1992, A. Salino 1309 (UEC); Brotas, Fazenda Santa Elisa, 8-IX-1991, A. Salino 1042 (UEC); Espírito Santo do Pinhal, Morro da Pedra do Ovo, 14-XI-1986, A. Salino 68 (UEC); Ubatuba, Parque Estadual Serra do Mar, 10-XI-1993, A. Salino 1860 (HRCB); idem, Parque Estadual da Ilha Anchieta, 7-VI-2000, E.C. Smidt 149 (SJRP); idem, Parque Estadual Serra do Mar, núcleo Picinguaba, 14-X-2000, A. Furlan \& C.E. Carneiro 1592 (HRCB); idem, Parque Estadual Serra do Mar, núcleo Picinguaba, 31-VIII-2001, D. G. Picchi 3 (HRCB); Jaci, Fazenda Bom Retiro, 13-IX-1992, M.R. Silva 427 (SJRP); Ubarana, Fazenda Santa Palmira, 18-V-2000, F.P.F. Athayde et al. 572 (SJRP); Ibaté, Reserva Florestal, 15-X-1999, A.R. Martins 4 (SJRP); Olímpia, Fazenda Mon Plaizir, 12-V-2000, F.P.F. Athayde \& A.H.S. Alves 513 (SJRP); Borborema, Sítio Santa Luzia, 21-XII-1996, M.R. Pietrobom-Silva 3933 (SJRP); Cubatão, Serra do Mar, 21-V-1995, M.R. PietrobomSilva 1773 (SJRP); Sete Barras, Parque Estadual Intervales, 13-IX-2000, V.B. Zipparro 1992 (HRCB); idem, 13-XI-2001, V.A.O. Dittrich 1010 (HRCB); Matão, 12-XII-2007, J. Prado et al. 1762 (SP).

Campyloneurum repens pode ser facilmente separada de $C$. nitidum pelo seu caule mais fino (ca. 4-5 mm diâm. em C. nitidum). Além disso, esta última espécie é caracterizada por suas escamas escuras, ovais e iridescentes, abundantes no caule, por sua lâmina foliar lanceolada e alongada, bem como pela venação primária conspícua e venação secundária obscura em ambas as faces da lâmina.

Foram encontrados exemplares previamente identificados como Campyloneurum minus Fée nos diferentes herbários visitados, sendo que estes exemplares foram re-determinados como $C$. repens. A espécie $C$. minus foi colocada como sinônimo de C. herbaceum (Christ.) Ching por León (1993a). Segundo a autora, enquanto $C$. repens possui escamas caulinares com células marginais hialinas, $C$. minus não as possui. No entanto, a utilização de tal característica para delimitação das espécies é ineficaz, uma vez que muitas variações ocorrem dentro de uma mesma espécie em relação a esta característica. Além disso, a descrição original de Polypodium herbaceum, realizada por Christ (Schwacke 1900), diz que esta espécie é distinta de $P$. repens pelas margens foliares crenadas e não pelas diferenças das escamas. A partir da observação do tipo de $P$. herbaceum depositado no Herbário de Paris (P) e dos representantes de C. repens dos herbários brasileiros, decidiu-se pela re-determinação dos espécimes identificados como C. minus para $C$. repens.

Campyloneurum repens apresenta uma distribuição relativamente ampla pelo estado de São Paulo, ocorrendo em municípios mais litorâneos, bem como em regiões mais ao norte do estado (figura 32 ).

9. Campyloneurum rigidum J. Sm., Cat. Kew Ferns 2. 1856.

Figuras 25-27, 32

Plantas epífitas. Caule curto-reptante, ca. $4 \mathrm{~mm}$ diâm., pruinoso, com escamas castanho-escuras, clatradas, arredondadas, base auriculada, aurículas simétricas, ápice arredondado, ca. 1-2 × $1 \mathrm{~mm}$, células arredondas, com lúmen iridescente e parede castanhoescura. Frondes 15-60 cm compr., monomorfas; filopódios $2 \times 5 \mathrm{~mm}$, distantes no máximo ca. $4 \mathrm{~mm}$ entre si; pecíolo 1-8 × 1-2 cm, paleáceo, robusto, glabro, alado, levemente sulcado adaxialmente; lâmina 10-50 × 1-2 cm, simples, lanceolada, subcoriácea a coriácea, glabra em ambas as faces, verde-amarelada e brilhante em ambas as faces; nervuras anastomosadas, obscuras em ambas as faces da lâmina, 2 ou 3 séries de aréolas entre a costa e a margem da lâmina, aréolas frequentemente divididas, 1 vênula livre por aréola. Soros 2 ou 3 fileiras entre a costa e a margem da lâmina, 1 soro por aréola.

Material examinado: BRASIL. São PAULO: Santos, Garujá, 7-I-1907, A. Usteri s.n. (SP22087); idem, Forte dos Andradas, 17-IX-1994, O. Yano \& Z.R. Mello 23138 (SP); idem, s.d., R. Wells-Windisch 1973 (SJRP); Ibiti, Fazenda Ponte Alta, 3-VIII-1946, M. Kuhlmann 1422 (SP); Gália, Reserva Florestal de Caetetus, 15-III-1981, O. Yano 3404 (SP); idem, Estação Ecológica Caetetus, 11-II-2003, T.B. Breier \& J. Breier 882 (UEC); idem, 11-II-2003, T.B. Breier \& J. Breier 888 (UEC); Ubatuba, Parque Estadual Serra do Mar, núcleo Picinguaba, 3-IX-1989, F.C.P. Garcia et al. 474 (HRCB); idem, Praia de Lagoinha, 25-XI-1997, D.C. Zappi \& C. Kameyama 29 (SPF); idem, Parque Estadual da Ilha Anchieta, 7-VI-2000, F.P.F. Athayde 647 (SJRP); idem, 18-II-2004, J. Prado et al. 1522 (SP); Cananéia, Ilha do Cardoso, 18-V-1977, A.T. Silva 49 (SP); idem, 18-VIII-2004, F. Barros et al. 3101 (SP); São Paulo, Alto da Serra, 1901, M. Wacket s.n. (SP21894); Bertioga, São Lourenço, 1-VI-1999, J. Prado et al. 1015 (SP); Iguape, Estação Ecológica Juréia-Itatins, Serra da Juréia, 28-31-V-1996, P. Labiak et al. 327 (SP); idem, Estação Ecológica de Chauás, 11-I-1999, 


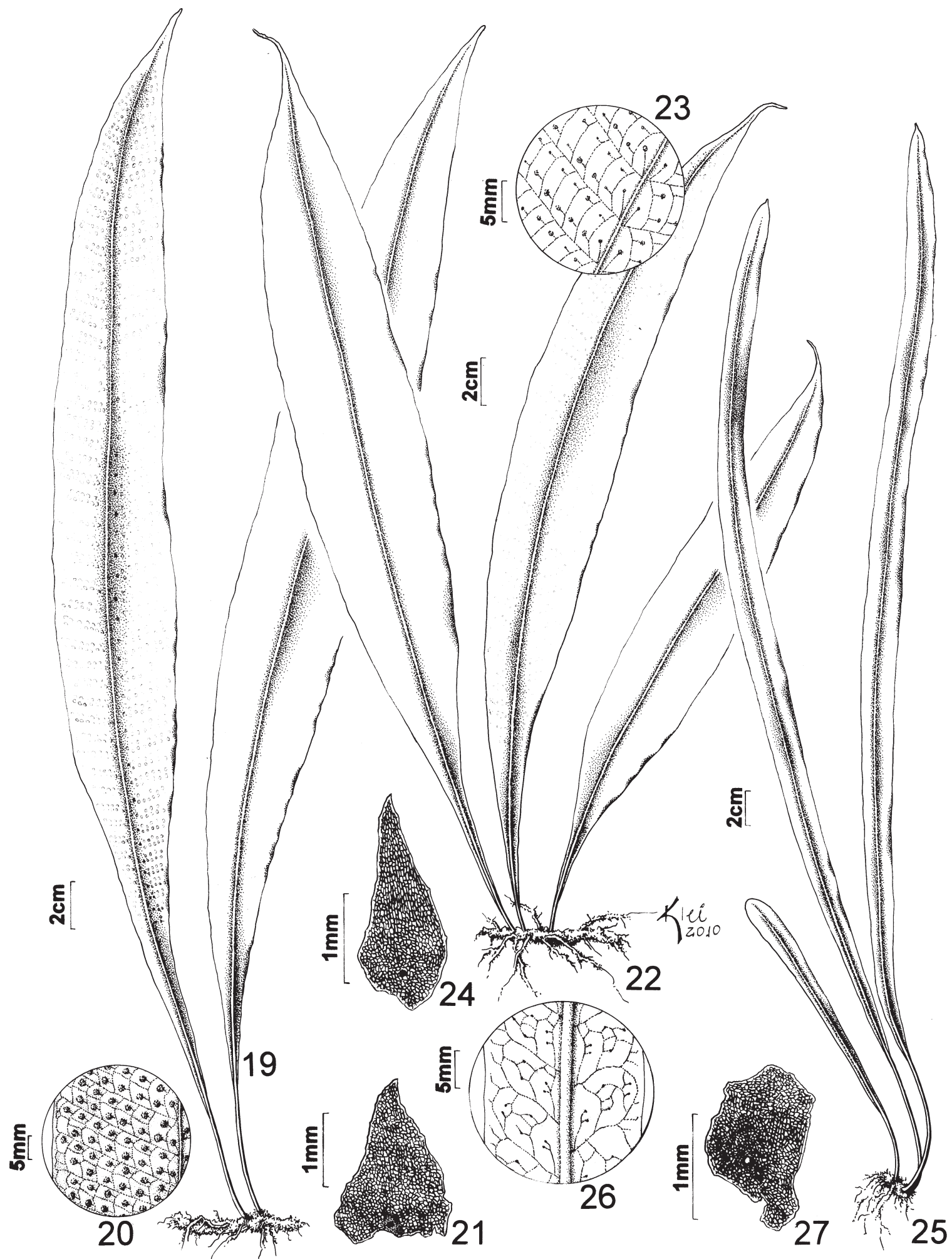

Figuras 19-27. Espécies de Campyloneurum do Estado de São Paulo. 19-21. Campyloneurum nitidum (Nicolau et al. 907, SP). 19. Hábito. 20. Detalhe das nervuras. 21. Detalhe da escama do caule. 22-24. C. repens (Souza 5741, SP). 22. Hábito. 23. Detalhe das nervuras. 24. Detalhe da escama do caule. 25-27. C. rigidum (Prado et al. 1015, SP). 25. Hábito. 26. Detalhe das nervuras. 27. Detalhe da escama do caule.

Figures 19-27. Species of Campyloneurum of the state of São Paulo. 19-21. Campyloneurum nitidum (Nicolau et al. 907, SP). 19. Habit. 20. Detail of the veins. 21. Detail of stem scale. 22-24. C. repens (Souza 5741, SP). 22. Habit. 23. Detail of the veins. 24. Detail of stem scale. 25-27. C. rigidum (Prado et al. 1015, SP). 25. Habit. 26. Detail of the veins. 27. Detail of stem scale. 


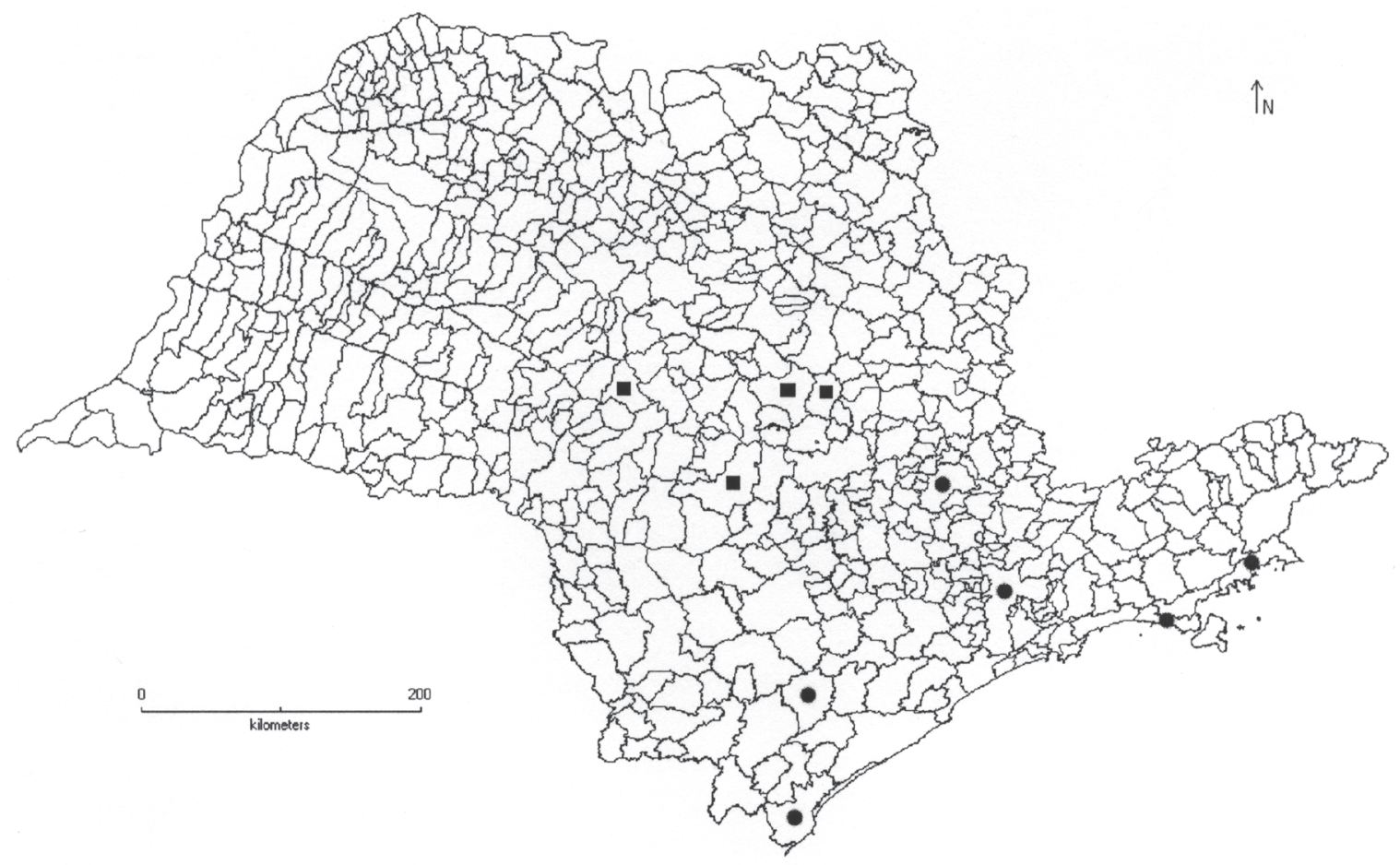

Figura 28. Distribuição geográfica de Campyloneurum acrocarpon $(\bullet)$ e C. aglaolepis (•) no Estado de São Paulo.

Figure 28. Distribution of Campyloneurum acrocarpon $(\bullet)$ and C. aglaolepis $(\boldsymbol{\bullet})$ in São Paulo State.

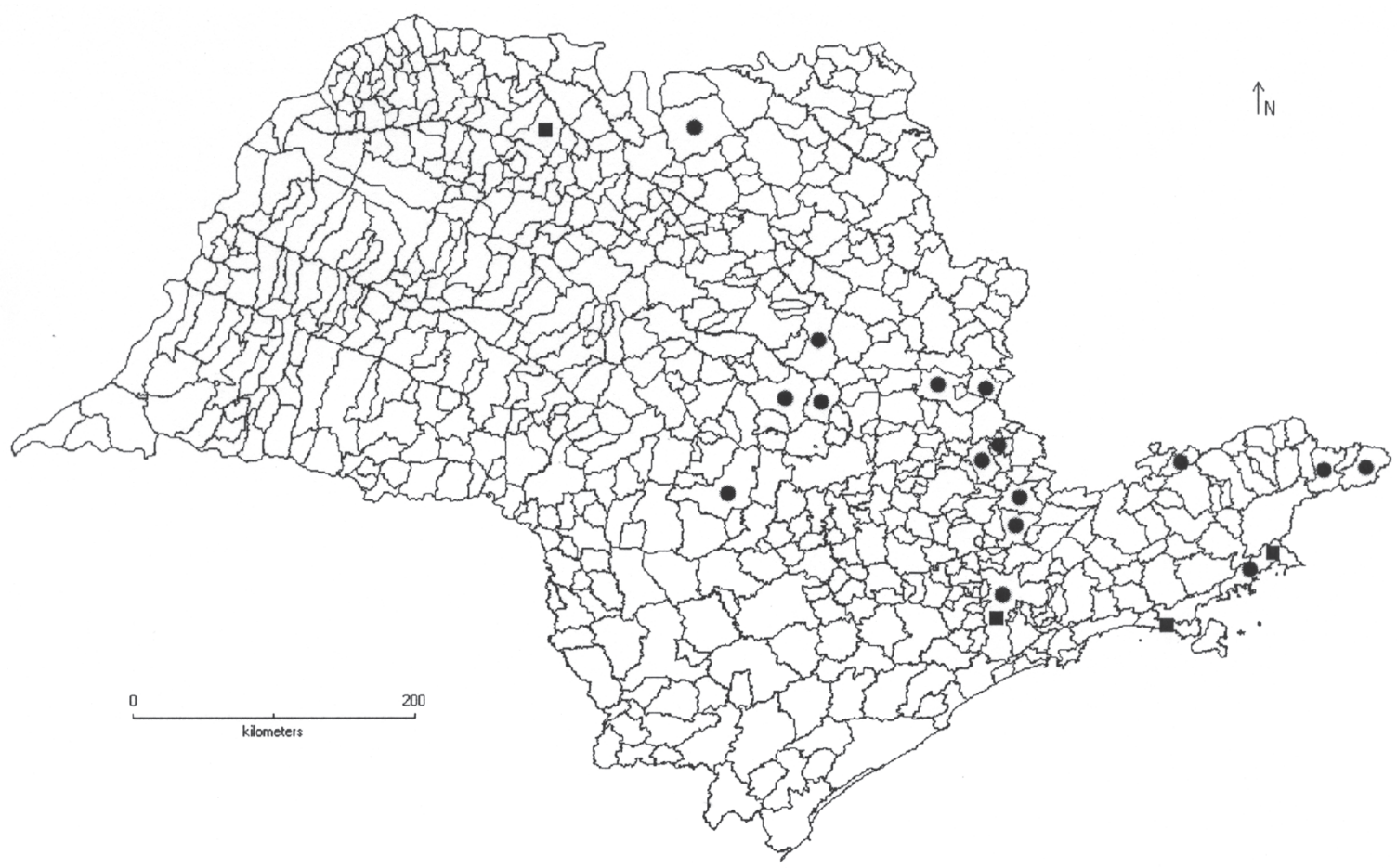

Figura 29. Distribuição geográfica de Campyloneurum angustifolium $(\bullet)$ e C. decurrens $(\bullet)$ no Estado de São Paulo.

Figure 29. Distribution of Campyloneurum angustifolium $(\bullet)$ and C. decurrens $(\bullet)$ in São Paulo State. 


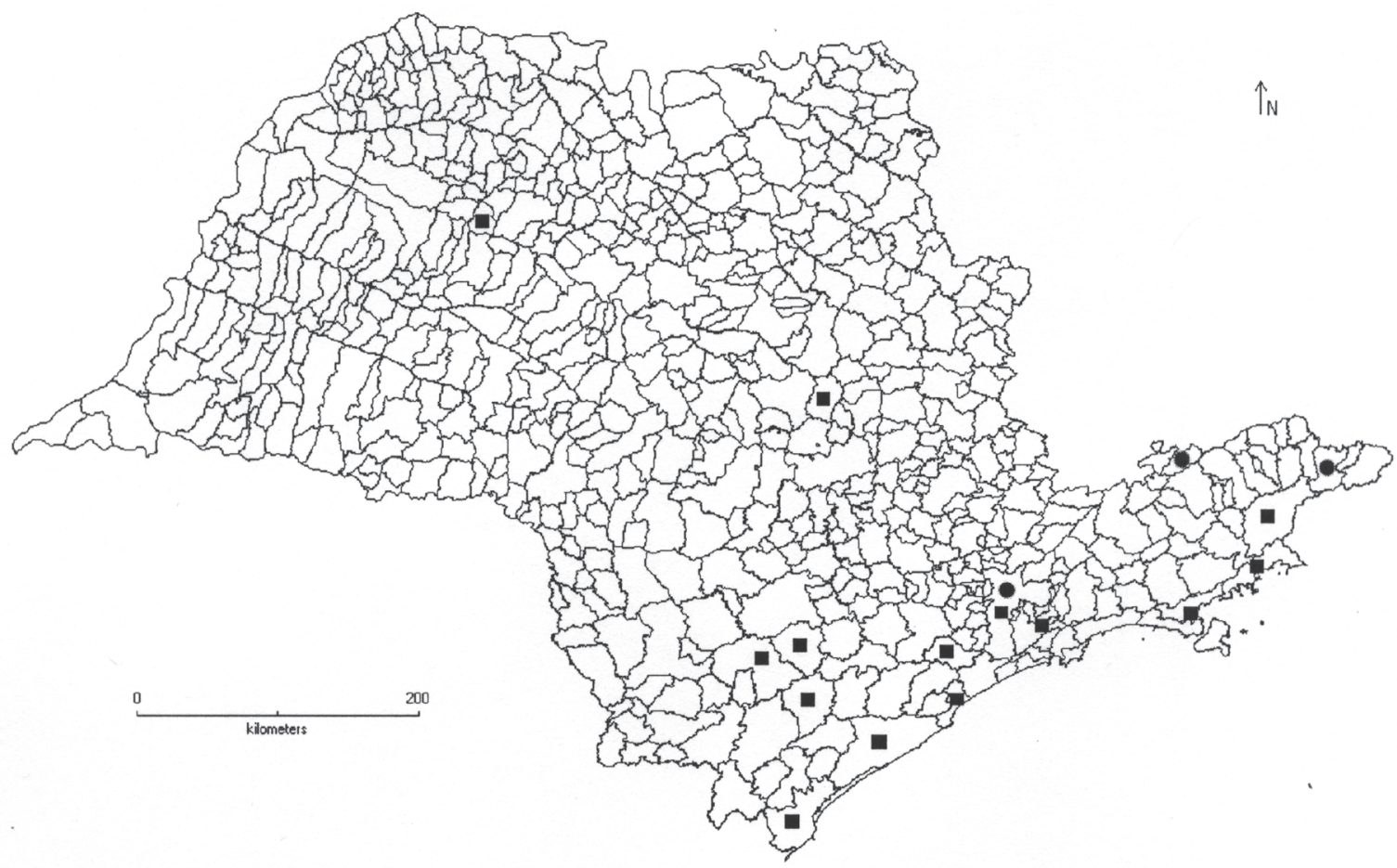

Figura 30. Distribuição geográfica de Campyloneurum fallax (•) e C. lapathifolium (匹) no Estado de São Paulo.

Figure 30. Distribution of Campyloneurum fallax $(\bullet)$ and C. lapathifolium $(\boldsymbol{\bullet})$ in São Paulo State.

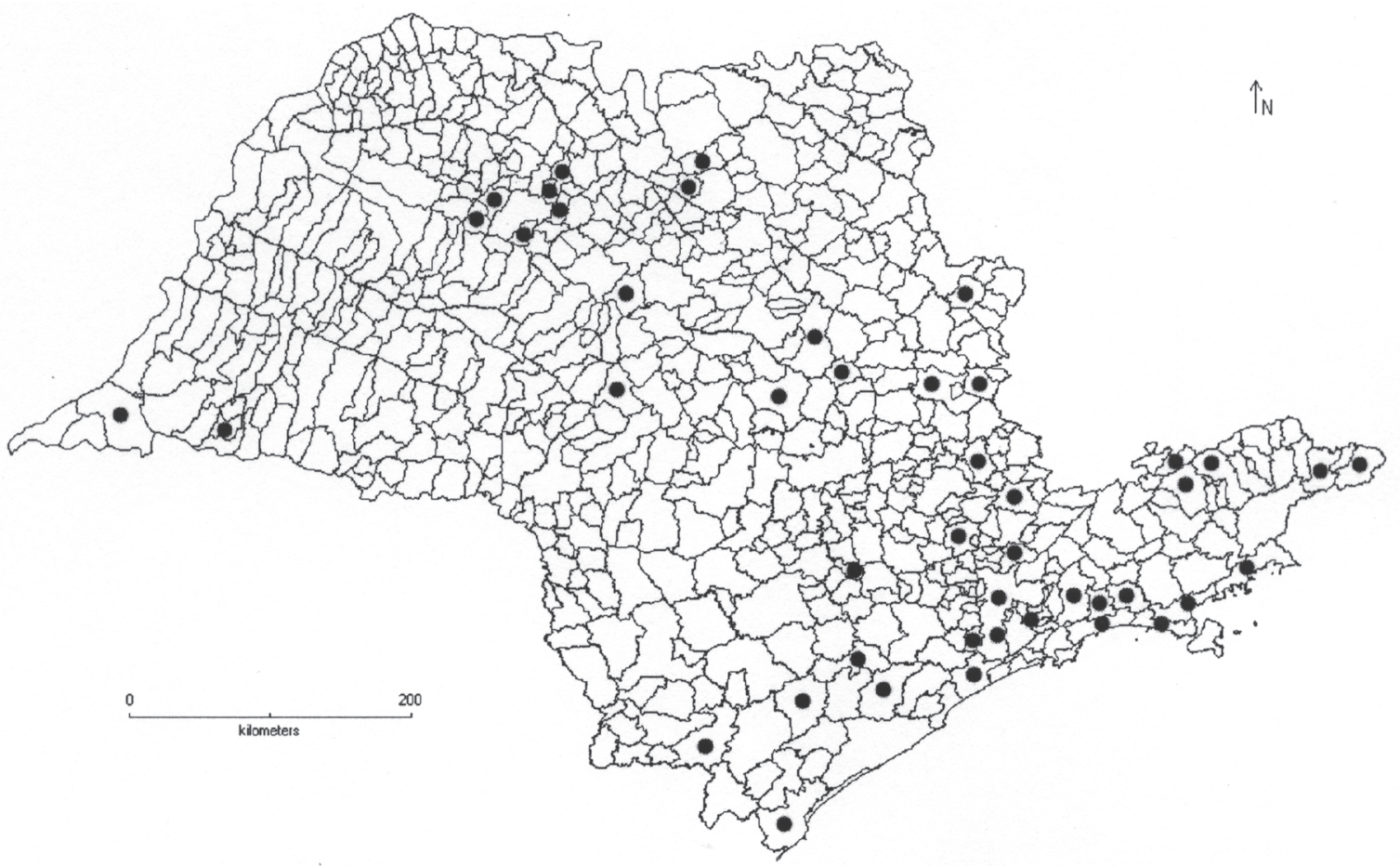

Figura 31. Distribuição geográfica de Campyloneurum nitidum no Estado de São Paulo.

Figure 31. Distribution of Campyloneurum nitidum in São Paulo State. 


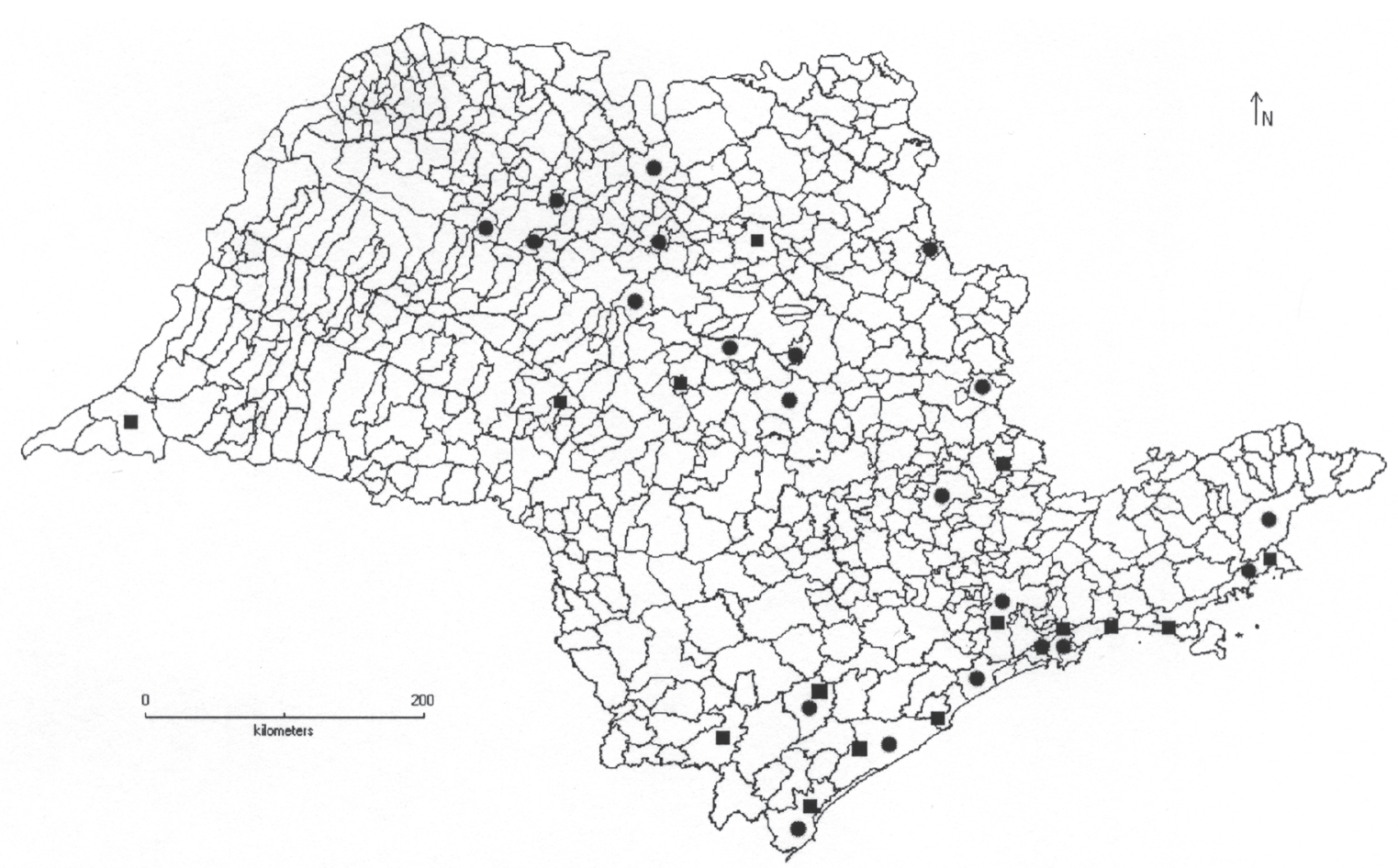

Figura 32. Distribuição geográfica de Campyloneurum repens $(\bullet)$ e C. rigidum (•) no Estado de São Paulo.

Figure 32. Distribution of Campyloneurum repens $(\bullet)$ and $C$. rigidum (घ) in São Paulo State.

C. Kozera et al. 853 (UEC); Teodoro Sampaio, 9-11-IX-1985, P.G. Windisch 4254 (SJRP); idem, 9-11-IX-1985, P.G. Windisch 4254-A (SJRP); idem, Parque Estadual Morro do Diabo, 16-I-1995, M.R. Silva 1589 (SJRP, SPF); idem, 17-I-1995, M.R. Silva 1631 (SJRP); idem, Fazenda Ponte Branca, 23-I-1995, M.R. Silva 1643 (SJRP); idem, Parque Estadual Morro do Diabo, 30-I-1995, M.R. Silva 1688 (SJRP); São Sebastião, Boiçucanga, 26-VII-1983, J.R. Pirani \& O. Yano 751 (SPF); Boracéia, 31-X-1987, R. Simão-Bianchini 8 (SPF); Sete Barras, Parque Estadual Carlos Botelho, 21-VIII-2002, T.B. Breier \& J.C. Budke 513 (UEC); idem, 26-IX-2002, T.B. Breier \& V.A.O. Dittrich 642 (UEC); idem, 27-IX-2002, V.A.O. Dittrich \& T.B. Breier 1208 (HRCB); Iporanga, 11-IV-1982, S. Gandolli 13483 (UEC); Jaboticabal, Campus UNESP, 25-X-1996, S.S. Cortezzi 14 (SJRP).

Campyloneurum rigidum é facilmente reconhecida pela sua lâmina foliar amarelo-esverdeada e brilhante, além de suas nervuras ocultas na lâmina foliar. Esta espécie tem distribuição restrita à região sudeste do Brasil (León 1993a, Lellinger 1988).

A espécie ocorre desde municípios litorâneos, até alguns municípios mais centrais e ocidentais do estado.
Há registros de ocorrência da espécie em Teodoro Sampaio, extremo oeste do estado (figura 32).

\section{Agradecimentos}

À FAPESP, pelo financiamento da pesquisa (bolsa de Iniciação Científica Proc. n. 2009/06898-3); ao Instituto de Botânica de São Paulo; aos Instituto de Biociências da Universidade de São Paulo, da Universidade Estadual de Rio Claro, da Universidade Estadual de São José do Rio Preto e da Universidade de Campinas; e aos meus amigos e professores. $\mathrm{O}$ segundo autor agradece ao $\mathrm{CNPq}$ pela bolsa de Produtividade Científica (Proc. n. 302732/2207-1).

\section{Literatura citada}

Boldrin, A.H.L. \& Prado, J. 2007. Pteridófitas terrestres e rupícolas do Forte dos Andradas, Guarujá, São Paulo, Brasil. Boletim de Botânica da Universidade de São Paulo 25: 1-69.

Hennipman, E., Veldhoen, P. \& Kramer, K.U. 1990. Polypodiaceae. In: K.U. Kramer \& P.S. Green (eds.). Pteridophytes and Gymnosperms. In: K. Kubitzki (ed.). The families and genera of vascular plants. Springer Verlag, Berlin, v. 1, pp. 203-230.

Kaulfuss, D.G.F. 1824. Enumeratio Filicum. Sumptibus C. Cnobloch, Lipsiae. 
Lellinger, D.B. 1988. Some new species of Campyloneurum and a provisional key to the genus. American Fern Journal 78: 14-35.

Lellinger, D.B. 2002. A modern multilingual glossary for taxonomic Pteridology. Pteridologia 2A. v. 3. American Fern Society, Washington.

León, B. 1993a. A taxonomic revision of the fern genus Campyloneurum (Polypodiaceae). Part. I. Tese de doutorado. Afhandling indleveret til det Naturvidenskabelige Fakultet ved Aarhus.

León, B. 1993b. Campyloneurum. In: R.M. Tryon \& R.G. Stolze. Pteridophyta of Peru - Part V - 18. Aspleniaceae -21 . Polypodiaceae. Fieldiana, Botany, new series 32: 158-173.

Mickel, J.T. \& Smith, A.R. 2004. The pteridophytes of Mexico. Memoirs of the New York Botanical Garden 88: 165-172.
Pichi Sermolli, R.E.G. 1973 Historical review of the higher classification of the Filicopsida. In: A.C. Jermy, J.A. Crabb \& B.A. Thomas (eds.). Phylogeny and classification of the ferns. Botanical Journal of the Linnean Society 67(Suppl. 1): 11-40.

Pichi Sermolli, R.E.G. 1996. Authors of scientific names in Pteridophyta. Royal Botanic Gardens, Kew.

Presl, C. 1836. Tentamen Pteridographiae. Typis Foliorum Theophili Haas, Pragae.

Schuettpelz, E. \& Pryer, K.M. 2007. Fern phylogeny inferred from 400 leptosporangiate species and three plastid genes. Taxon 56: 1037-1050.

Schwacke, W. 1900. Plantas Novas Mineiras, fasc. II., Imprensa Oficial, Belo Horizonte.

Smith, A.R., Pryer, K.M., Schuettpelz, E., Korall, P., Schneider, H. \& Wolf, P.G. 2006. A classification for extant ferns. Taxon 55: 705-731.

Stearn, W.T. 1983. Botanical Latin. David \& Charles, London. 